\title{
METHODS OF ENLIGHTENMENT OF THE GENERAL PUBLIC ON VENEREAL DISEASES *
}

\author{
By Col. L. W. HARRISON, D.S.O., F.R.C.P.
}

STRICTLY speaking, the subject of this discussion is rather outside the province of our Society, which was formed for the study of the individual venereal diseases and their management, not to stimulate the general public to make use of our knowledge. The Council of this Society thought, however, that enlightenment of the lay public on these diseases was very important just now and that perhaps we were the only organisation that could easily arrange a free discussion of the subject, on neutral ground that was easily accessible to most of those interested in it.

I do not propose to read you a lecture on the methods of enlightenment of the general public on venereal diseases because I am no expert in this branch and I want to give the fullest possible opportunity to those who feel inclined to do so to give us here the benefit of their views on the subject.

My task is mainly to suggest the headings under which the subject might be discussed, though at the same time I may perhaps be allowed to indicate where I think some revision of commonly held views might be desirable.

First, I take it, we need not waste time over declaring the value of public enlightenment on venereal diseases, because that goes without saying. It is axiomatic that if everybody knew as mucn about these diseases as we do, there would soon be an end of them because everybody who became infected would at once take advantage of knowledge and resources that are now quite sufficient for their eradication.

Nor need we spend any time sighing for the B.B.C. to screw up its courage to allow broadcasting of the facts about venereal diseases. We can agree that probably broadcasts would be most useful, but we can more profitably use the short time we have to-day for discussion of methods that are more immediately applicable.

The public to be considered for purposes of enlightenment may be divided into school children and older persons. As regards school children, although there may be differences of opinion on the lengths to which instruction in sex hygiene may go at school and when it should be started, probably most would accept the proposition that good instruction of children in the elements of natural science would help our anti-venereal measures. It would enable people as children and later as adults to take an intelligent interest in the happenings around them and to rely on their own resources rather than on spoon-fed amusements for employment of their leisure. It would, moreover, prepare them for more direct enlightenment on sex hygiene.

With regard to enlightenment of older persons, I think we might

* Opening remarks at a discussion held by the Medical Society for the Study of Venereal Diseases on March 28th, 1942. 


\section{THE BRITISH JOURNAL OF VENEREAL DISEASES}

discuss the question under the headings of lectures and films and of literature.

On lectures and films I confess that in recent years my own views have undergone some modification, and, at the risk perhaps of generating some heat here, I am going to suggest that their value has been over-rated.

For a number of years I have known that, in spite of repeated exhortations by the Ministry of Health to maintain a steady stream of enlightenment on V.D., a number of County Councils and County Borough Councils in England have shown themselves by no means zealous in the performance of their duties in this respect, and this has led to some enquiries to discover the cause.

In I937, in order to obtain an idea of the position in regard to education of the public and of the views of local authorities on this question, the Ministry of Health issued a questionnary in rather general terms. It did not elicit all the information which we wanted, or the frank expressions of opinion for which I had hoped, but we gathered from the replies that in a rather large number of areas enlightenment of the public by lectures and films dealing with venereal diseases had been a very spasmodic affair, and 26 authorities replied bluntly that for a number of years they had undertaken no propaganda other than advertisement of facilities for diagnosis and treatment of venereal diseases.

Amongst other things, we asked if lectures had resulted in any increase in new cases at treatment centres. A certain number reported that there had been some increase but practically all who did so said also that the additional new cases had mostly been found not to have venereal disease of any kind.

I visited a number of these authorities to discover, if possible, why they were so indifferent to enlightenment of the public on venereal diseases and gathered from most of them that they thought that lectures achieved only little in relation to their cost. Some spoke of poor attendances and some said that audiences at these lectures consisted mainly of three kinds of people, namely, those who had contracted one of the venereal diseases and wanted to discover what they were in for; those who had run risks, and the morbidly curious including those who were incapable of contracting V.D. I judged that they thought that young people who would have benefited by a timely warning had not troubled to attend these lectures.

It seemed desirable to extend these enquiries, and in the early months of 1939, at a number of conferences of Medical Officers of Health and Venereal Disease Officers to discuss anti-venereal arrangements in the event of war, I took the opportunity to canvas opinions on ways and means of enlightening the public on venereal diseases. Here again I could not elicit many frank opinions but could not discover any great enthusiasm for lectures and films, nor indeeed for ad hoc literature, and the general impression which I gathered, rightly or wrongly, from these enquiries was that the demand for ad hoc instruction on venereal diseases is much below what one would consider necessary for adequate enlightenment of the public.

My enquiries led me to another line of investigation, an attempt to estimate the proportion of the population at risk who attended 


\section{METHODS OF ENLIGHTENMENT ON VENEREAL DISEASES}

lectures and film shows given under the auspices of the British Social Hygiene Council, and the result did not impress me. I will not detail the figures and ratios which I worked out because it will suit my purpose to quote from those arrived at by Dr. Hartley of Scientific Computing Services Ltd., which were published in "Health and Empire" for September I94I.

Dr. Hartley analysed the figures relating to estimated sizes of audiences at courses of instruction and at lectures, exhibitions and film shows organised by the British Social Hygiene Council during the ten years I930 to I940; he took into account also the numbers of persons estimated to have been taught by those who had attended the courses of instruction just mentioned. His conclusion from all his calculations was that approximately 35 per cent. of the population aged 15 to 50 had been "reached " by these methods of enlightenment. The analysis showed that, if this percentage was correct, by far the majority of those said to have been "reached "- -in fact, 944 in every r, Ioocannot have attended a lecture or a film show on the subject more than once in the ten years. Of the remaining 156 in each $I$, IOO, 9 attended a course of instruction of 2 or 3 lectures and the remaining 147 were made up of those supposed to have been taught by those who had attended courses. In the case of approximately 500 of the 944 the attendance was at a film show under commercial auspices. If any of the 944 attended a lecture or a film show more than once in the ten years, it would, of course, mean a corresponding lowering of the proportion of the population calculated to have been reached.

Accepting Dr. Hartley's estimates at their face value, I suggest that lectures and film shows attended only once in ten years by only I in 3 of the population aged 15 to 50 cannot be said to have gone very far in enlightening the population at risk on the subject of venereal diseases. Can they have made much more impression than the posters displayed in the public lavatories? Incidentally, does anyone here think that, if he were to ask every person he met if he had attended a lecture or a film show on venereal diseases during the past ten years and the person so questioned were to answer " aye" or " no," there would be 60 " ayes " in 200? I am afraid I do not.

The cost of these lectures, etc. is stated to have been $£ \mathrm{I} 66,455$ odd, and this sum was spent on enlightenment by these means of only six of the eleven million odd persons who made up the 35 per cent. said to have been " reached," the balance consisting of those who paid to see commercial films on the subject. One judges then that enlightenment by lectures is expensive in relation to the results achieved in terms of persons enlightened and intensity of enlightenment.

On the reasonable assumption that the lecturers were the best obtainable and the matter beyond reproach, can we discover by discussion here the reasons for the lack of enthusiasm for this form of instruction which is reflected by the data I have given?

\section{EDUCATION BY Literature}

In the recommended list of the British Social Hygiene Council are over Ioo books and pamphlets, and one has only to read a few of them to realise the amount of valuable information that is available on this important subject at very small cost. In fact one would say that, 


\section{THE BRITISH JOURNAL OF VENEREAL DISEASES}

if every young man and every young woman would only read one or two of the pamphlets which could easily be selected from the British Social Hygiene Council's recommended list, the public would be sufficiently enlightened for the purposes of our anti-venereal measures.

Yet my own enquiries at the conferences which I have mentioned did not lead me to believe that literature on this subject was in great demand. I made suggestions designed to advertise this literature locally, making it obtainable at the public health departments, but they did not evoke any enthusiasm. Will you tell us why?

My own feeling is that the average young man or woman is afraid of being caught with ad hoc literature on venereal diseases in his or her possession. It is silly, of course, but it is based on the same foundation as the fact that philanthropists are shy of having their names associated with financial contributions to research on venereal diseases.

So far my remarks have been only destructive, so by way of concluding them I would like to make a constructive suggestion. It is that effort should be concentrated on the making of a general popular work on the preservation of health, which would contain the important facts on venereal diseases in as concentrated a form as possible. Such a work would be the health lecturer's bible, and the aim would be to get it into every household in the country.

No one person could write this book, and in this connexion I will quote the following from the pamphlet entitled "Education and Social Hygiene" by Prof. Sir Arthur Thomson and published by the British Social Hygiene Council : "Our suggestion is that direct verbal sex instruction is so extremely difficult that the British Social Hygiene Council should undertake the preparation of a co-operatively produced book of guidance, embodying all the wisdom we have from all sides, and readily available to all who wish it."

I suggest that this might be expanded to embrace not only sex hygiene but all that pertains to preservation of health, and I commend the suggestion to the notice of the Central Council for Health Education.

\section{METHODS OF ENLIGHTENMENT OF THE GENERAL PUBLIC ON VENEREAL DISEASES}

\section{Discussion}

Dr. Otтo MAY having said that he had been privileged to collaborate with Colonel Harrison in much of his work, traced the National Council for Combating Venereal Diseases, from its origin to its present broader scope as The British Social Hygiene Council.

He did not recollect that Col. Harrison, the liaison officer between the National Council and the Ministry of Health, had put forward constructive suggestions for altering their methods. Col. Harrison mentioned the comparatively small number of people reached by films and lectures. True these methods did not reach every citizen, but much useful work had thereby been done. True also, a large number of people had nevir attended any of these meetings. But he had been surprised by the number of young recruits who in reply to his question,

"Have you had any instruction in sex hygiene?" said that they had seen the films.

A general book on health, with a section on venereal diseases, as Col. Harrison 